\title{
Burn Management at the 37 Military Hospital-A Tertiary Hospital in Accra, Ghana
}

\section{Kwesi Okumanin Nsaful ${ }^{1 *}$, Edward Asumanu ${ }^{2}$, Yaa Konadu Asante-Mante ${ }^{1}$, Jeffery Eduku Mozu ${ }^{1}$, Jennifer Maame Efua Owusu1, Emmanuel Yaw Botchway1, Amma Gyamfuawaa Afriyie1, Stephen Mawuli Dei ${ }^{1}$, Edmund Tettey Nartey ${ }^{3}$, Richard Osei Boateng ${ }^{4}$}

\author{
${ }^{1}$ Plastics and Burn Centre, 37 Military Hospital, Accra, Ghana \\ ${ }^{2}$ General Surgery Unit, 37 Military Hospital, Accra, Ghana \\ ${ }^{3}$ Statistics and Data Analysis Department, Korle Bu Teaching Hospital, Accra, Ghana \\ ${ }^{4}$ Records and Data Collection Division, 37 Military Hospital, Accra, Ghana \\ Email: *knsaful@yahoo.co.uk
}

How to cite this paper: Nsaful, K.O., Asumanu, E., Asante-Mante, Y.K., Mozu, J.E., Owusu, J.M.E., Botchway, E.Y., Afriyie, A.G., Dei, S.M., Nartey, E.T. and Boateng, R.O. (2022) Burn Management at the 37 Military Hospital-A Tertiary Hospital in Accra, Ghana. Modern Plastic Surgery, 12, $1-12$.

https://doi.org/10.4236/mps.2022.121001

Received: November 28, 2021

Accepted: January 22, 2022

Published: January 25, 2022

Copyright $\odot 2022$ by author(s) and Scientific Research Publishing Inc. This work is licensed under the Creative Commons Attribution International License (CC BY 4.0).

http://creativecommons.org/licenses/by/4.0/

\begin{abstract}
Burn injuries have been and remain a very significant source of mortality and morbidity in low- and middle-income countries. As a country in this category, Ghana, is not exempted. Ghana has a population of 31 Million with only 21 Plastic Reconstructive and Burn surgeons. Moreover, the country can boast of only 3 major Burn centres. This notwithstanding the country in particular and Africa, in general, carries an extraordinary burden of Burn injuries with devastating consequences. Burn data from the 37 Military Hospital were analyzed from March 2018 to September 2019-a period of 18 months. In all, 217 burn cases were seen representing about $2.1 \%$ of all trauma and surgical cases. Our burn data analyzed the peculiarities of epidemiology, types of burn, the pattern of injuries, and the outcome of burn care at the 37 Military Hospital. Flame is emerging as the predominant cause of burns, most frequently occurring from the use of Liquid Petroleum Gas. In the pediatric population, however, the most frequent cause of burns is hot water burns. The mortality rate among the burn population was $1.8 \%$ (4 mortalities). This paper aims to point out management methods adopted by our unit which helped to improve burn outcomes and to reduce mortality.
\end{abstract}

\section{Keywords}

Burns, Wound Healing, Wound Dressing, Burn Blisters, Antibiotics

\section{Introduction}

Ghana has a landmass of $238,535 \mathrm{~km}^{2}(92,099 \mathrm{sq} \cdot \mathrm{mi})$ [1]. Ghana has a popula- 
tion of approximately 31 million [2].

Ghana currently has only 21 Plastics and Burn surgeons. Moreover, there are only 3 Burn Centres with the oldest unit less than 2 decades old. Incidentally, it was established through the assistance of Mr. Jack Mustarde, (A Scottish Plastic Surgeon) who received an OBE for that work.

Burn injuries impact negatively the quality of life of patients. Burns present situations of high economic burden for patients and their relatives. Burns undoubtedly continue to be a major problem especially in developing countries affecting all ages. Burn injuries may occur as a result of flames, electricity, chemicals, hot liquids, or contact with any hot object. Deforming scars and debilitating contracture, as well as death, are always possible complications from burn injuries. Therefore, it is critical that efforts be placed at preventing burns along with having systems in place to adequately and appropriately manage burns when they occur.

This work seeks to study the epidemiology of burns in an attempt to find guidelines to enhance burn prevention. This work also seeks to take a critical look at some management methods pointing out the pros and cons of these methods.

\section{Method}

\section{Study Design}

The study was a prospective study. The inclusion criteria were all patients with burn wounds who presented to the Trauma Surgical Emergency Unit of the 37 Military Hospital. During the period of the study-March 2018 to September 2019-a period of 18 months.

The data collected included the following:

- patient's demographics.

- aetiology of injury.

- the extent of burns (\%TBSA).

- Admission outcome.

Statistical analysis was done using SPSS v. 21.

\section{Results}

Children under 5 years formed $23.5 \%$ of all the burn cases (Table 1). Males outnumbered females 52.1 - 47.9 (Table 1).

Table 1. Socio-demographic characteristics of study participants.

\begin{tabular}{clcc}
\hline Characteristics & & Frequency & Proportion (\%) \\
\hline \multirow{2}{*}{ Age Group } & $<5$ years & 51 & 23.5 \\
& $5-18$ years & 35 & 16.1 \\
& $>18$ years & 131 & 60.4 \\
Sex & Male & 113 & 52.1 \\
& Female & 104 & 47.9 \\
\hline
\end{tabular}


During the period of study, $42.6 \%$ of the patients presented with mild burns, 28.7\% presented with Moderate burns while another $28.7 \%$ presented with Severe burns (Table 2).

For this study Mild burns is defined as burn with Total Body Surface Area (TBSA) of Less than 10\%, Moderate Burns as burns involving 10\%-20\% TBSA while Severe burns was burns involving greater than $20 \%$ TBSA.

Hot water burns were the most frequent cause of burn injuries accounting for 69 (32.9\%) of all burn cases (Table 2). Road Traffic Accidents formed the Second most common cause of burns forming almost $1 / 5^{\text {th }}(19.5 \%)$ of all burn cases (Table 2).

Out of the total of 206 patients 4 of them died resulting in a mortality rate of $1.9 \%$ (Table 2).

With parts of the body involved in the burns, the upper limbs were the commonest parts involved (Table 2).

In all the age categories Hot water burns served as the most frequent cause of burn injuries. Hot water burns formed $42.9 \%$ of all burns in children under 5 years, $27.3 \%$ of all burns in children aged 5 - 18 years while $30.5 \%$ of all burns in people older than 18 years was as a result of hot water (Table 3 ).

For the Source of burn based on the gender of the patients, among males and females there with little or no difference, comparatively in the source of burn.

Table 2. Clinical characteristics of study participants.

\begin{tabular}{clcc}
\hline Characteristic & & Frequency & Proportion (\%) \\
\hline \multirow{2}{*}{ Burn severity } & Mild & 52 & 42.6 \\
& Moderate & 35 & 28.7 \\
& Severe & 35 & 28.7 \\
Source of burn & Hot water & 69 & 32.9 \\
& RTA & 41 & 19.5 \\
& Hot liquid & 32 & 15.2 \\
& Gas explosion & 32 & 15.2 \\
& Flame & 23 & 11.0 \\
& Electrical & 11 & 5.2 \\
& Chemical & 2 & 1.0 \\
& & & \\
Body part involved & & & \\
& Upper limbs & 121 & 55.8 \\
& Lower limbs & 82 & 37.8 \\
& Head \& neck & 72 & 33.2 \\
& Trunk & 68 & 31.3 \\
& & & \\
Admission outcome & Discharged & 202 & 98.1 \\
& Died & 4 & 1.9 \\
\hline
\end{tabular}

${ }^{1}$ Percentages may add up to $>100$ as a patient may have more than one body part involved. 
Table 3. Burn characteristics based on age category.

\begin{tabular}{|c|c|c|c|}
\hline \multirow[b]{2}{*}{ Characteristics } & \multicolumn{3}{|c|}{ Age Group } \\
\hline & $\begin{array}{c}<5 \text { years } \\
n, \%^{1}\end{array}$ & $\begin{array}{c}5 \text { - } 18 \text { years } \\
n, \%^{1}\end{array}$ & $\begin{array}{c}>18 \text { years } \\
n, \%^{1}\end{array}$ \\
\hline Burn severity & $\mathrm{N}=24$ & $\mathrm{~N}=22$ & $N=76$ \\
\hline Mild & $10(41.7)$ & $5(22.7)$ & $37(48.7)$ \\
\hline Moderate & $11(45.8)$ & $7(31.8)$ & $17(22.4)$ \\
\hline Severe & $3(12.5)$ & $10(45.5)$ & $22(28.9)$ \\
\hline Source of burn & $\mathrm{N}=49$ & $N=33$ & $\mathrm{~N}=128$ \\
\hline Hot water & $21(42.9)$ & $9(27.3)$ & $39(30.5)$ \\
\hline Road traffic accident & $10(20.4)$ & $7(21.2)$ & $24(18.8)$ \\
\hline Hot liquid & $5(10.2)$ & $5(15.2)$ & $22(17.2)$ \\
\hline Gas explosion & $4(8.2)$ & $8(24.2)$ & $20(15.6)$ \\
\hline Flame & $6(12.2)$ & $2(6.1)$ & $15(11.7)$ \\
\hline Electrical & $3(6.1)$ & $1(3.0)$ & $7(5.5)$ \\
\hline Chemical & $0(0)$ & $1(3.0)$ & $1(0.8)$ \\
\hline Body part involved $^{1}$ & $\mathrm{~N}=48$ & $\mathrm{~N}=31$ & $\mathrm{~N}=128$ \\
\hline Upper limbs & $24(50.0)$ & $24(77.4)$ & $73(57.0)$ \\
\hline Lower limbs & $18(37.5)$ & $9(29.0)$ & $55(43.0)$ \\
\hline Head \& neck & $18(37.5)$ & $11(35.5)$ & $43(33.6)$ \\
\hline Trunk & $11(22.9)$ & $15(48.4)$ & $42(32.8)$ \\
\hline Admission outcome & $\mathrm{N}=46$ & $\mathrm{~N}=31$ & $\mathrm{~N}=129$ \\
\hline Discharged & $46(100)$ & $30(96.8)$ & $126(97.7)$ \\
\hline Died & $0(0)$ & $1(3.2)$ & $3(2.3)$ \\
\hline
\end{tabular}

${ }^{1}$ Percentages may add up to $>100$ as a patient may have more than one body part involved; Column percentages.

However, with Gas explosion there was a male preponderance $17.1 \%$ to $13.1 \%$ in Females (Table 4).

\section{Discussion}

In developed countries, burn injuries account for more than 50,000 admissions with a mortality rate of $5 \%-36.12 \%$ [3] [4] [5] [6]. However, when complicated with inhalation injury, the death rate increases with a reported mortality rate of over 30\% [3]. With 217 burn cases over the 18 month period, burn injuries formed about $2.1 \%$ of all the presentations at the Trauma and surgical emergency of the 37 Military Hospital in Accra Ghana. This implies approximately 12 new burn cases per month.

Hot water burns were the most frequent cause of burn injuries forming 32.9\% of all burn cases. It was worthy of note that most of the hot water burns occurred 
Table 4. Burn characteristics based on gender.

\begin{tabular}{|c|c|c|}
\hline \multirow[b]{2}{*}{ Characteristic } & \multicolumn{2}{|c|}{ Gender } \\
\hline & $\begin{array}{l}\text { Male } \\
n, \%^{1}\end{array}$ & $\begin{array}{c}\text { Female } \\
\mathrm{n}, \%^{1}\end{array}$ \\
\hline Burn severity & $N=63$ & $\mathrm{~N}=59$ \\
\hline Mild & $24(38.1)$ & $28(47.5)$ \\
\hline Moderate & $20(31.8)$ & $15(25.4)$ \\
\hline Severe & $19(30.2)$ & $16(27.1)$ \\
\hline Source of burn & $\mathrm{N}=111$ & $N=99$ \\
\hline Hot water & $37(33.3)$ & $32(32.3)$ \\
\hline Road traffic accident & $21(18.9)$ & $20(20.2)$ \\
\hline Hot liquid & $16(14.4)$ & $16(16.2)$ \\
\hline Gas explosion & $19(17.1)$ & $13(13.1)$ \\
\hline Flame & $12(10.8)$ & $11(11.1)$ \\
\hline Electrical & $5(4.5)$ & $6(6.1)$ \\
\hline Chemical & $1(0.9)$ & $1(1.0)$ \\
\hline Body part involved ${ }^{1}$ & $\mathrm{~N}=108$ & $\mathrm{~N}=99$ \\
\hline Upper limbs & $61(56.5)$ & $60(60.6)$ \\
\hline Lower limbs & $46(42.6)$ & $36(36.4)$ \\
\hline Head \& neck & $41(38.0)$ & $31(31.3)$ \\
\hline Trunk & $34(31.5)$ & $34(34.3)$ \\
\hline Admission outcome & $\mathrm{N}=109$ & $\mathrm{~N}=97$ \\
\hline Discharged & $107(98.2)$ & $95(97.9)$ \\
\hline Died & $2(1.8)$ & $2(2.1)$ \\
\hline
\end{tabular}

${ }^{1}$ Percentages may add up to $>100$ as a patient may have more than one body part involved; Column percentages.

in association with attempts to have a bath with hot water. Interestingly, Road Traffic Accidents formed the second most common cause of burns forming almost $1 / 5^{\text {th }}$ of all burn cases, further underlining the menace that Road Traffic Accidents present.

Our centre has over the period employed a treatment regimen which has been developed after a careful study of burn management in various centres. This regimen has been couched and tailored with the aim of providing our burn wounds, as far as we can, with the optimum conditions for wound healing.

\subsection{The use of Silver Sulfadiazine}

In Ghana Silver Sulfadiazine (often in the form of Dermazine cream) is easily the most frequently used topical agent for dressing of burn injuries. It is a white, highly insoluble compound that is synthesized from silver nitrate and sodium 
sulfadiazine [7] [8]. It is available in $1 \%$ concentration in a water-soluble cream base. The cream is relatively painless to apply and has an in vitro activity against a wide range of organisms including $S$. aureus, E. coli, Klebsiella species, Pseudomonas aeruginosa, Proteus species, and Candida albicans [8].

However, there are quite a few downsides to the use of Silver Sulfadiazine. Acute hemolytic anemia has been reported in burn patients treated with silver sulfadiazine who lacked the enzyme glucose- 6 phosphatase [9]. The most frequently associated clinical finding is a transient leukopenia that occurs within several days of the initiation of therapy. This is associated with a disproportionate decrease in circulating neutrophils. The incidence is from $5 \%$ to $15 \%$ of patients treated [10], and it has been proposed that there is a direct toxic effect of silver sulfadiazine on bone marrow. Some of the benefits of this topical agent are its ease of use and its ability to reduce pain. It has some tissue-penetrating ability, but is limited to the surface epidermal layer Thus tissue penetration is poor [11] [12].

Another disadvantage to the use of Silver Sulfadiazine is that the antimicrobial effectiveness has been observed to last for up to 24 hours [8]. This implies that the agent has to be applied on a daily or twice-daily basis. When this is not adhered to the cream becomes a broth, a medium for bacteria culture in the wound.

In our situation dressings are done after every 72 hours. With this regimen, our patients and their relatives have to spend about $\$ 300$ each week. This is already a huge financial strain on patients and their families. Twice daily dressings will mean $\$ 1400$ on the average per week for each patient.

Another shortcoming to the use of Silver Sulfadiazine is the possibility that it may retard epithelialization [13].

For these reasons we, in our centre, have stayed away from the use of Silver Sulphadiazine. This in our opinion has resulted in good epithelialization of wounds and have avoided all the problems associated with the use of Silver Sulfadiazine.

\subsection{Management of Blisters}

Recommendations for the management of burn blisters are varied and range from leaving blisters intact [14], to removing the blistered skin immediately [15], or delaying removal [16]. This lead author recommends leaving burn blisters intact. Blisters form in the stratum spinosum layer of the epidermis. An intact blister usually indicates a superficial partial-thickness wound, which will heal spontaneously within 3 weeks. If, under these circumstances, the blistered skin is removed, the wound is converted from an absolutely painless one to a painful one, this also elicits the metabolic response to trauma [17]. It may further result in an open wound exposed to colonization by bacteria and potential infection [14]. Additionally it is the opinion of this author that that blistered skin serves as a biological dressing of the wound. It is also very rare to have an infection of 
burn wound with intact blisters. Therefore, this lead author prefers to leave blisters intact, and recommends that they be dressed gingerly protecting the blisters (Figure 1).

\subsection{Bathing of Patients}

Patients who are ambulatory are encouraged to have a supervised shower prior to wound dressing. Bathing in the Bath tub is discouraged as soon as the patient is found to be ambulatory. Though there is no empirical evidence, there is always the possibility that the use of a single bathtub for all the burn patients may lead to cross-infection no matter how conscientious the staff maybe with cleaning and decontamination of the bath in between patients.

\subsection{Our Regimen}

In 2003, the International Wound Bed Preparation Advisory Board established an algorithmic approach to wound management with the development of the 'T.I.M.E.' acronym [18] [19]. This Identified four components of wound bed preparation, which address the different pathophysiological abnormalities underlying chronic wounds:

1) Tissue management.

2) Inflammation and infection control.

3) Moisture balance.

4) Epithelial (edge) advancement.

The T.I.M.E. framework comprises the comprehensive strategies that can be applied to the management of different types of wounds to maximize the potential for wound healing [20].

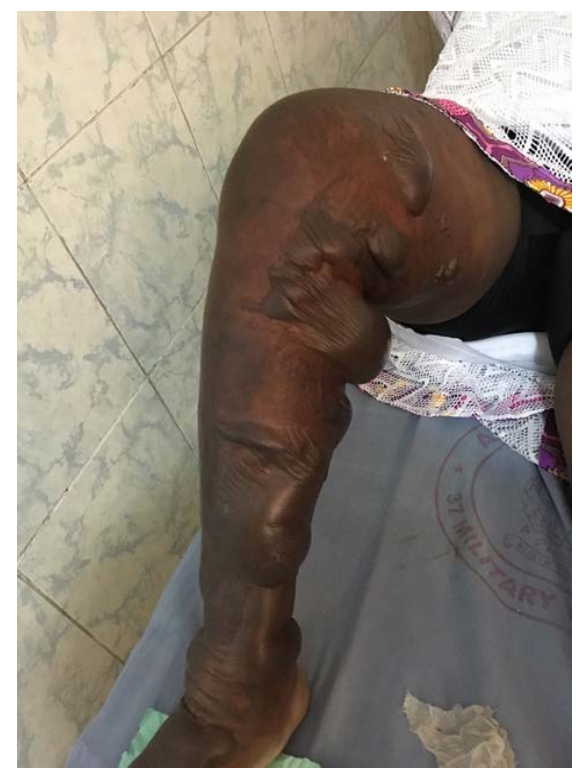

(a)

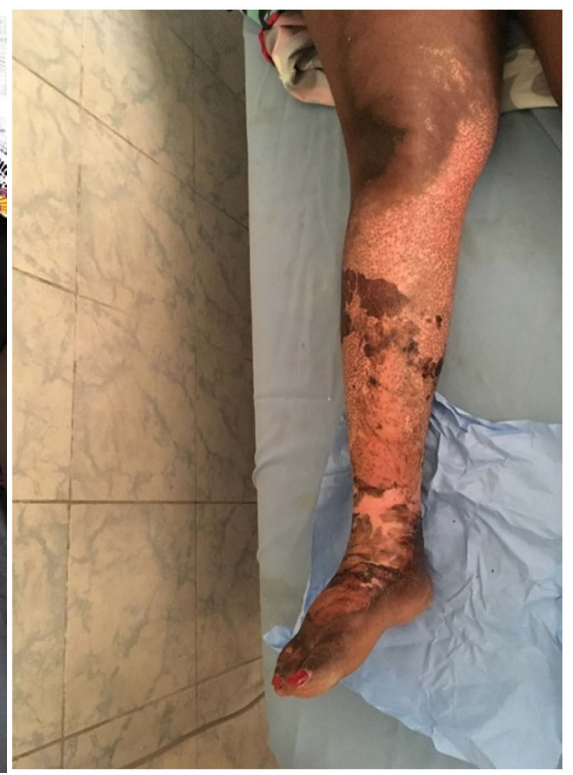

(b)

Figure 1. (a) Patient with Burn Blisters; (b) 14 Days post management without Breaking Blisters. 
Winter's seminal paper from 1962 showed that a moist wound environment accelerates healing. According to his work wounds heal 50\% faster if kept moist (Winter, 1962) [21]. Moist wounds enhance the regrowth of new skin (epithelialisation). Other studies have also shown that a moist wound prevents tissue dehydration and cell death [22].

Our centre employs the use of Vaseline gauze for burn wound dressing. The use of Vaseline gauze is seen as the nearest, easiest and the most cost-effective method of dressing that helps one to achieve the TIME concept.

Vaseline Gauze is a sterile, occlusive dressing consisting of fine-mesh, absorbent gauze impregnated with approximately three times its weight of white petrolatum.

Petrolatum impregnate remains moist to minimize drying out and adherence. It acts by sealing water into the skin.

The non-adherent fine mesh reduces pain and trauma during dressing changes

- The gauze also Conforms to body contours to help seal air leaks and unwanted fluid loss.

- It is generally non-toxic, non-sensitizing and non-irritating.

When using Vaseline the wound will scab less and the new skin will be less raised (or not at all).

\subsection{The Use of Antibiotics}

Infection is common in burns because the injury causes the skin to lose its natural barrier to microbes; this allows pathogens to have a direct entry route to the wound. Bacteria and fungi are the most common pathogens found in burn wounds; these can originate from the patient's own skin, gut and respiratory microflora, as well as through contact with the hospital environment or healthcare workers [23] [24].

In addition, burn wounds usually produce high levels of exudate, which creates a suitably moist, nutrient-rich environment for bacterial growth [25] [26] and may result in infection [27]. Infection of burn wounds can delay healing and encourage scarring. Furthermore, without appropriate treatment, an infection may develop into something more serious, such as multi-organ dysfunction syndrome or invasive infections, such as bacteraemia, or sepsis [28]. Data from the French Burns Centres indicates that $19 \%$ of inpatients with burns develop an infection [29]. Thus, not all burn patients develop wound infection.

It is difficult to diagnose whether a burn wound is infected or not because the burn injury itself can appear inflamed, which is a symptom of infection. Secondly, the presence of micro-organisms in the wound does not necessarily mean that it is infected. However, sometimes, colonisation can shift to infection: this progression depends on three factors, namely, host immune function, the level of bacterial inoculum and bacterial virulence [30]. According to the guidelines of the French Society for Burn Injuries (SFETB), antibiotics should be administered once an infection has been diagnosed [31]. Thus the advice is that anti- 
biotics should be used only when wound infection is diagnosed in a burn patient.

In our centre antibiotics are initiated on presentation. Intravenous antibiotics (IV Ceftazidime) is routinely used based on work done by the author [32]. Antibiotics are initiated on presentation because most of the burn patients apply topical "first aid" prior to presentation at the hospital. Some of the substances applied to the wounds as "first aid" include, Gentian violet, Ashes from the coal pot, sawdust, toothpaste, seawater, Vaseline petroleum gel, Aloe Vera ointment, milk and egg yolk. Some have even presented to the hospital after applying cow dung as "first aid" (Figure 2).

The burn wound is initially sterile from the heat however the application of these topical substances makes the wound contaminated -most likely leading to infection. Depending on the substances applied as "first aid" antibiotic cover for anaerobes is added (IV Metronidazole).

\section{Conclusions}

Burn injuries are often related to poverty and consequently, the majority of the burden of disease is borne by people in the lowest socio-economic groups living in the poorest countries, and yet there has been little significant change in either the incidence or the outcomes in these regions [33].

About $90 \%$ of all burns are preventable [34]. This fact indicates that effort can be put in place to decrease the incidence of burns.

Adequate education of the general public about the dangers of burns and how to prevent burns will go a long way to reduce the burden of burn injuries. For example, people should be taught to take a bucket of cold water to the kitchen to mix the hot water in the kitchen rather than transporting hot steaming buckets of water to the bathroom. Similarly, the Ghanaian public should be encouraged to stand lit candles on non-combustible materials. In the use of LPG Cylinders safety precautions such as keeping the cylinders outside and passing the tube

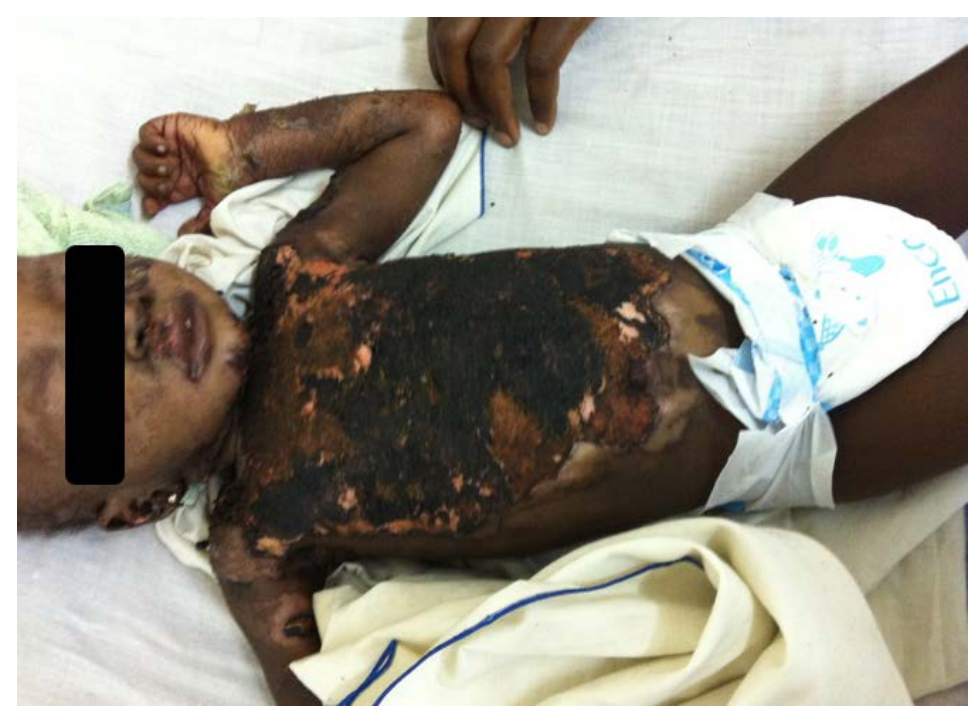

Figure 2. Month old child with burn injuries dressed with cow dung. 
through the wall to the connecting stove should be made the norm.

\section{Patient Consent}

Written consent was sort from the patient in order for them to participate the study. Additionally, written consent was sort for the use of the images.

\section{Author Contribution}

All authors contributed to all processes in this work, including patient selection, data collection, data analysis, and manuscript writing.

\section{Conflicts of Interest}

The authors declare no conflicts of interest regarding the publication of this paper.

\section{References}

[1] Government of Ghana (2010) Ghana-2010 Population and Housing Census. Government of Ghana, Accra.

[2] Worldometers (2020) Ghana Population. https://www.worldometers.info/world-population/ghana-population/.

[3] Bloemsma, G.C., Dokter, J., Boxma, H. and Oen, I.M.M.H. (2008) Mortality and Causes of Death in a Burn Centre. Burns, 34, 1103-1107. https://doi.org/10.1016/j.burns.2008.02.010

[4] Olaitan, P.B. and Jiburum, B.C. (2006) Analysis of Burn Mortality in a Burns Centre. Annals of Burns and Fire Disasters, 19, 59-62.

[5] Agbenorku, P., Aboah, K., Akpaloo, J., Amankwa, R., Farhat, B., Turkson, E., HoyteWilliams, P.E. and Klutsey, E.E. (2016) Yorke Epidemiological Studies of Burn Patients in a Burn Center in Ghana: Any Clues for Prevention? Burns \& Trauma, 4, Article ID: s41038-016-0041-0. https://doi.org/10.1186/s41038-016-0041-0

[6] Ibran, E., Mirza, F.H., Memon, A.A., Farooq, M.Z. and Hassan, M. (2013) Mortality Associated with Burn Injury-A Cross Sectional Study from Karachi, Pakistan. BMC Research Notes, 6, Article No. 545. https://doi.org/10.1186/1756-0500-6-545

[7] Monafo, W.W. and West, M.A. (1990) Current Treatment Recommendations for Topical Burn Therapy. Drugs, 40, 364-373. https://doi.org/10.2165/00003495-199040030-00004

[8] Fox Jr., C.L. (1968) Silver Sulfadiazine-A New Topical Therapy for Pseudomonas in Burns. Therapy of Pseudomonas Infection in Burns. Archives of Surgery, 96, 184188. https://doi.org/10.1001/archsurg.1968.01330200022004

[9] Eldad, A., Neuman, A., Weinberg, A., Benmeir, P., Rotem, M. and Wexler, M.R. (1991) Silver Sulphadiazine Induced Haemolytic anaemia in a Glucose-6-Phosphate Dehydrogenase-Deficient Burn Patient. Burns, 17, 430-432. https://doi.org/10.1016/S0305-4179(05)80083-X

[10] Choban, P.S. and Marshall, W.J. (1987) Leukopenia Secondary to Silver Sulfadiazine: Frequency, Characteristics and Clinical Consequences. The American Surgeon, 53, 515-517.

[11] Heggers, J.P., Sazy, J.A., Stenberg, B.D., Strock, L.L., McCauley, R.L., Herndon, D.N., et al. (1991) Bactericidal and Wound Healing Properties of Sodium Hypoch- 
lorite. Journal of Burn Care \& Research, 12, 420-424.

[12] Fuller, A.T., Mellows, G., Woolford, M., Banks, G.T., Barrow, K.D. and Chain, E.B. (1971) Pseudomonic Acid, an Antibiotic Produced by Pseudomonas fluorescens. Nature, 234, 416-417. https://doi.org/10.1038/234416a0

[13] Muller, M.J., Hollyoak, M.A., Moaveni, Z., Brown, T.L., Herndon, D.N. and Heggers, J.P. (2003) Retardation of Wound Healing by Silver Sulfadiazine Is Reversed by Aloe vera and Nystatin. Burns, 29, 834-836. https://doi.org/10.1016/S0305-4179(03)00198-0

[14] Swain, A.H., Azadian, B.S., Wakeley, C.J. and Shakespeare, P.G. (1987) Management of Blisters in Minor Burns. British Medical Journal (Clinical Research Ed.), 295, Article No. 181. https://doi.org/10.1136/bmj.295.6591.181

[15] Rockwell, W.B. and Ehrlich, H.P. (1990) Should Burn Blister Fluid Be Evacuated? Journal of Burn Care \& Research, 11, 93-95. https://doi.org/10.1097/00004630-199001000-00020

[16] Demling, R.H. and LaLonde, C. (1989) Burn Trauma (Trauma Management Series). Vol. 4, Blaisdell, F.W. and Trunkey, D.D., Eds., Thieme Publishing Group, New York, 55-56.

[17] Badoe, E.A., Archampong, E.Q. and Jaja, M.O.A. (Eds.) (1986) Principles and Practice of Surgery Including Pathology in the Tropics. 4th Edition, Ghana Publishing Company, Tema.

[18] Sibbald, R.G., Orsted, H., Schultz, G.S., Coutts, P. and Keast, D. (2003) Preparing the Wound Bed 2003: Focus on Infection and Inflammation. Ostomy Wound Management, 49, 23-51.

[19] Schultz, G.S., Sibbald, R.G., Falanga, V., Ayello, E.A., Dowsett, C., Harding, K., et al. (2003) Wound Bed Preparation: A Systematic Approach to Wound Management. Wound Repair and Regeneration, 11, S1-S28. https://doi.org/10.1046/j.1524-475X.11.s2.1.X

[20] Halim, A.S., Khoo, T.L. and Mat Saad, A.Z. (2012) Wound Bed Preparation from a Clinical Perspective. Indian Journal of Plastic Surgery, 45, 193-202. https://doi.org/10.4103/0970-0358.101277

[21] Bryan, J. (2004) Moist Wound Healing: A Concept That Changed Our Practice. Journal of Wound Care, 13, 227-228. https://doi.org/10.12968/jowc.2004.13.6.26625

[22] Nicholson, B. (2016) How to Heal Open Wounds Faster. Sun Oven. https://www.sunoven.com/how-to-heal-open-wounds-faster/

[23] D’Avignon, L.C., Saffle, J.R., Chung, K.K. and Cancio, L.C. (2008) Prevention and Management of Infections Associated with Burns in the Combat Casualty. Journal of Trauma, 64, S277-S286. https://doi.org/10.1097/TA.0b013e318163c3e4

[24] Gosain, A. and Gamelli, R.L. (2005) Role of the Gastrointestinal Tract in Burn Sepsis. Journal of Burn Care \& Rehabilitation, 26, 85-91. https://doi.org/10.1097/01.BCR.0000150212.21651.79

[25] Çakır, B. and Yeğen, B.Ç. (2004) Systemic Responses to Burn Injury. Turkish Journal of Medical Sciences, 34, 215-226.

[26] Greenfield, E. and McManus, A.T. (1997) Infectious Complications: Prevention and Strategies for Their Control. The Nursing Clinics of North America, 32, 297-309.

[27] Ramakrishnan, M.K., Sankar, J., Venkatraman, J. and Ramesh, J. (2006) Infections in Burn Patients_Experience in a Tertiary Care Hospital. Burns, 32, 594-596. https://doi.org/10.1016/j.burns.2005.11.018

[28] Fitzwater, J., Purdue, G.F., Hunt, J.L. and O'Keefe, G.E. (2003) The Risk Factors and 
Time Course of Sepsis and Organ Dysfunction after Burn Trauma. The Journal of Trauma: Injury, Infection, and Critical Care, 54, 959-966. https://doi.org/10.1097/01.TA.0000029382.26295.AB

[29] Ravat, F., Floch, R., Vinsonneau, C., Ainaud, P., Bertin-Maghit, M., Carsin, H., et al. (2011) Antibiotics and the Burn Patient. Burns, 37, 16-26.

https://doi.org/10.1016/j.burns.2009.10.006

[30] Brusselaers, N., Monstrey, S., Snoeij, T., Vandijck, D., Lizy, C. and Hoste, E., et al. (2010) Morbidity and Mortality of Blood Stream Infections in Patients with Severe Burn Injury. American Journal of Critical Care, 19, e81-e87.

https://doi.org/10.4037/ajcc2010341

[31] Lu, J., Yang, M., Zhan, M., Xu, X., Yue, J. and Xu, T. (2017) Antibiotics for Treating Infected Burn Wounds. Cochrane Database of Systematic Reviews, No. 7, Article No. CD012084. https://doi.org/10.1002/14651858.CD012084.pub2

[32] Nsaful, K., Paintsil, A., Dakubo, J., Nsaful, J., Appiah-Labi, K. and Nartey, E. (2020) Evaluation of Bacterial Infection of Split-Thickness Skin Grafts at the Korle $\mathrm{Bu}$ Teaching Hospital. Bali Medical Journal, 9, 259-265.

https://doi.org/10.15562/bmj.v9i1.1760

[33] Golshan, A., Patel, C. and Hyder, A.A. (2013) A Systematic Review of the Epidemiology of Unintentional Burn Injuries in South Asia. Journal of Public Health, 35, 384396. https://doi.org/10.1093/pubmed/fds102

[34] Rybarczyk, M.M., Jesse, M., Schafer, J.M., Elm, C.M., Sarvepalli, S., Pavan, A., Vaswani, P.A., Balhara, K.S., Carlson, L.C. and Jacquetahi, G.A. (2017) A Systematic Review of Burn Injuries in Low- and Middle-Income Countries: Epidemiology in the WHO-Defined African Region. African Journal of Emergency Medicine, 7, 30-37. https://doi.org/10.1016/j.afjem.2017.01.006 